\title{
Biological Matrices and Synthetic Meshes Used in Implant-based Breast Reconstruction - a Review of Products Available in Germany
}

\section{Biologische Matrizes und synthetische Netze im Rahmen der implantatgestützten Brustrekonstruktion - Eine Übersicht verfügbarer Materialien in Deutschland}

Authors

Affiliations
M. Dieterich ${ }^{1,3}$, A. Faridi ${ }^{2,3}$

1 Universitätsfrauenklinik und Poliklinik, University of Rostock, Rostock, Germany

2 Senology, Vivantes Klinikum Am Urban, Berlin, Germany

${ }^{3}$ Working Group of the German Society of Obstetrics and Gynecology for Plastic, Aesthetic and Reconstructive Surgery in Gynecology (AWOgyn)

\section{Key words \\ - breast cancer \\ - breast reconstruction \\ - biological matrix \\ - synthetic mesh \\ - ADM \\ Schlüsselwörter \\ - Mammakarzinom \\ - Brustrekonstruktion \\ - biologische Matrix \\ - synthetische Netze \\ - ADM}

\section{received 2.7.2013 \\ revised 20.8.2013 \\ accepted 16.9.2013}

Bibliography

Dol http://dx.doi.org/

10.1055/s-0033-1350930

Geburtsh Frauenheilk 2013; 73 :

1100-1106 @ Georg Thieme

Verlag KG Stuttgart · New York. ISSN 0016-5751

\section{Correspondence}

\section{Dr. Max Dieterich}

University of Rostock

Universitätsfrauenklinik und Poliklinik

Südring 81

18059 Rostock

max.dieterich@uni-rostock.de

\section{Abstract \\ $\nabla$}

While autologous breast reconstruction was considered the procedure of choice for immediate breast reconstruction, there has been a shift towards implant-based breast reconstruction (IBBR) in recent years. The proven safety of silicone breast implants and the development of biological matrices and synthetic meshes have contributed to the growing popularity of this approach. Although these different products are widely used, only limited clinical data are available with regard to breast surgery. The aim of this review was to give an overview of available biological matrices and synthetic meshes and discuss their use in clinical practice.

\section{Background}

$\nabla$

Since skin- and nipple-sparing mastectomies (SSM/NSM) have proven to be oncologically safe procedures, the number of immediate breast reconstruction (BR) procedures has substantially increased [1]. With SSM and NSM, the gland is completely removed and the skin envelope preserved, facilitating subsequent reconstruction. Historically, BR was performed in less than $25 \%$ of all breast cancer (BC) patients [2]. Whilst autologous BR used to be the treatment of choice, the last decade has seen a shift from autologous BR towards implant-based breast reconstruction (IBBR), which is now used in $37 \%$ of all BC patients in the USA [2]. As the number of autologous procedures has remained approximately the same, the increase in the number of immediate BR procedures can be primarily attributed to an increase in implant/expander reconstructions. Whether these data can be transferred to Germany is debatable, as the reimbursement systems in Germany differ from those in the US. The reimburse-

\section{Zusammenfassung \\ $\nabla$}

War die autologe Brustrekonstruktion lange Zeit das bevorzugte Operationsverfahren im Rahmen der Sofortrekonstruktion, ist in den letzten Jahren eine Verschiebung hin zur implantatgestützten Brustrekonstruktion zu beobachten. Die nachgewiesene Sicherheit von Silikonimplantaten und die Entwicklung biologischer Matrizes und synthetischer Netze haben zu dieser Entwicklung beigetragen. Obwohl diese unterschiedlichen Produkte breite Anwendung finden, liegen nur wenige klinische Daten zur Brustrekonstruktion vor. Ziel dieser Arbeit war es, einen Überblick über die zur Verfügung stehenden biologischen Matrizes und synthetischen Netze zu geben und deren Anwendung kritisch zu diskutieren.

ment of complex reconstructive procedures (pedicle and free flaps) is not the same in the US as in Germany, and these procedures are reimbursed proportionally less than IBBR, contributing to an increase in IBBR procedures [3]. Reasons for the increase in IBBR in Germany include increasing numbers of prophylactic contralateral mastectomies, improvements in the safety of silicone implants, a higher patient acceptance of silicone implants and the development of new surgical procedures and products for IBBR. Compared to autologous BR procedures, donor site morbidity has improved and the extent of surgery required and patient morbidity have decreased [4$6]$. With the development of biological matrices and synthetic meshes, patients who were initially unsuited for, or who did not desire, autologous BR can now be offered implant-based reconstruction.

In IBBR the implant is usually placed in a sub-pectoral pocket. The pectoral muscle serves as cover towards the maximal thinned out mastectomy flap. Implant coverage can often be achieved only 
Table 1 Overview of synthetic meshes approved for breast reconstruction in Germany.

\begin{tabular}{|c|c|c|c|}
\hline & TiLOOP ${ }^{\circledR}$ Bra extralight & SERAGYN BR ${ }^{\circledR}$ & TIGR $^{\circledR}$ Mesh (non-permanent scaffold) \\
\hline Material & $\begin{array}{l}\text { titanium-coated } \\
\text { polypropylene }(30-50 \mathrm{~nm})\end{array}$ & $\begin{array}{l}\text { resorbable part: } \\
\text { polyglycol acid - caprolacton } \\
\text { non-resorbable part: } \\
\text { polypropylene }\end{array}$ & $\begin{array}{l}\text { fast resorbing fiber is a copolymer of lactide, glycolide } \\
\text { and trimethylene carbonate } \\
\text { slow-resorbing fiber is a copolymer of lactide and tri- } \\
\text { methylene carbonate (completely absorbed after } 3 \text { years) }\end{array}$ \\
\hline Filament & monofilament & monofilament & warp-knitted polymers \\
\hline Base weight $\left(\mathrm{g} / \mathrm{m}^{2}\right)$ & 16 & & n.a. \\
\hline - Before resorption & - & 85 & \\
\hline After resorption & - & 28 (resorbable within $90-120$ days) & \\
\hline Pore size $(\mathrm{mm})$ & $\geq 1.0$ & & $\begin{array}{l}1 \text { at the time of implantation } \\
1 \times 2 \text { at } 4 \text { months }\end{array}$ \\
\hline - Resorbable part & - & 2 & \\
\hline - Non-resorbable part & - & 4 & \\
\hline Strength $(\mathrm{mm})$ & 0.2 & $\begin{array}{l}0.5 \text { (before resorption) } \\
0.2 \text { (after resorption) }\end{array}$ & n.a. \\
\hline Filament diameter & $65 \mu \mathrm{m}$ & $0.15 \mathrm{~mm}$ & $0.51 \mathrm{~mm}$ \\
\hline Tensile strength (grab test) & $\begin{array}{l}37 \mathrm{~N} / \mathrm{cm} \\
-\end{array}$ & $\begin{array}{l}67 \mathrm{~N} / \mathrm{cm} \text { (before resorption) } \\
41 \mathrm{~N} / \mathrm{cm} \text { (after resorption) }\end{array}$ & $86.6 \mathrm{~N} / \mathrm{cm}$ \\
\hline $\begin{array}{l}\text { Physiological elasticity } \\
\text { at } 16 \mathrm{~N} / \mathrm{cm}\end{array}$ & $23 \%$ & $\begin{array}{l}\text { lengthwise: } 14 \% / \text { crossways } 50 \% \\
\text { (before resorption) } \\
\text { lengthwise: } 25 \% / \text { crossways } 69 \% \\
\text { (after resorption) }\end{array}$ & $7 \%$ \\
\hline
\end{tabular}

n. a.: not available, cm: centimeter, mm: millimeter; N: Newton

for the upper and lower medial quadrant. No tissue from the pectoral muscle is usually available for the lower lateral part to provide additional cover or support the implant. This can lead to increased implant palpability with a lack of support and subsequent skin erosion. Additional coverage can be obtained by mobilizing the serratus or the anterior layer of the rectus muscle. But this approach involves even more trauma to native tissue and may technically not be possible in all patients. Thin patients, in particular, have no reserves to mobilize extra tissue at the lower lateral part where the breast is most vulnerable. The introduction of biological matrices (acellular dermal matrix [ADM]) into breast surgery has helped to resolve surgical restrictions in IBBR by allowing the surgeon to cover the implant even when native skin cover is insufficient. In addition to offering additional coverage, these products help to fix the pectoralis major muscle to the inframammary fold and stabilize the implant pocket laterally, without destroying additional tissue. Since the first reports on the use of ADMs in IBBR by Breuing et al., further supporting biological and synthetic materials have been introduced. To prevent any misunderstanding, in our review we use the terms "matrices" for biological materials and "meshes" for synthetic materials. Both materials are used in oncological patients. The aim of this review was to give an overview of the different materials available for IBBR in Germany and discuss their use in clinical practice.

\section{Approved Materials for Breast Reconstruction in Germany}

In Germany, seven biological matrices and three synthetic meshes have been approved for use in IBBR procedures. The different types and synthetic features are shown in 0 Tables $\mathbf{1}$ and $\mathbf{2}$, and the available products are discussed in more detail below.

\section{Synthetic meshes}

TiLOOP ${ }^{\circledR}$ Bra

The TiLOOP ${ }^{\circledR}$ Bra (pfm medical, Cologne, Germany) is the most commonly used synthetic mesh in Germany. It is made of non-resorbable, titanized, lightweight polypropylene (PP) with a monofilament structure ( Fig. 1). Titanium coating has been found to reduce inflammatory reaction, and there is significantly less shrinkage compared to identical, non titanium-coated, heavyweight PP meshes [7]. There were only three citations for the TiLOOP ${ }^{\circledR}$ Bra in PubMed. A single case report with histological evaluation of the TiLOOP ${ }^{\circledR}$ Bra reported only a mild inflammatory reaction and endothelial cells with good neovascularization [8]. Clinical evaluation of a TiLOOP ${ }^{\circledR}$ Bra mesh after $2 \frac{1}{2} 2$ months showed that the mesh fibers had embedded well in the surrounding tissue. An in vitro study and real-time cell analysis confirmed the good biocompatibility of the TiLOOP ${ }^{\circledR}$ Bra [9]. First clinical results indicate that TiLOOP ${ }^{\circledR}$ Bra and other synthetic meshes should be predominantly used in primary cases [10]. A large retrospective multicenter study of 231 procedures revealed seroma rates of only $4.8 \%$, but mesh explantation had to be performed in $7.8 \%$, and revisionary surgery was needed in $13.4 \%$ [11].

\section{SERAGYN ${ }^{\circledR}$ BR}

The SERAGYN ${ }^{\circledR}$ BR mesh (SERAG WIESSNER, Naila, Germany) is a tightly woven, partially resorbable mesh. The resorbable part is absorbed within 90-120 days while the non-resorbable part remains in place for additional support. Although surgeons have reported more difficult intraoperative handling due to its firmer characteristics, in vitro investigation and real-time cell analysis at our institute showed that the biocompatibility of the SERAGYN ${ }^{\circledR}$ BR mesh was similar to that of the TiLOOP ${ }^{\circledR}$ Bra [9]. With the exception of a summary reporting its use in 23 patients, no clinical data are available for SERAGYN ${ }^{\circledR}$ BR [12]. 


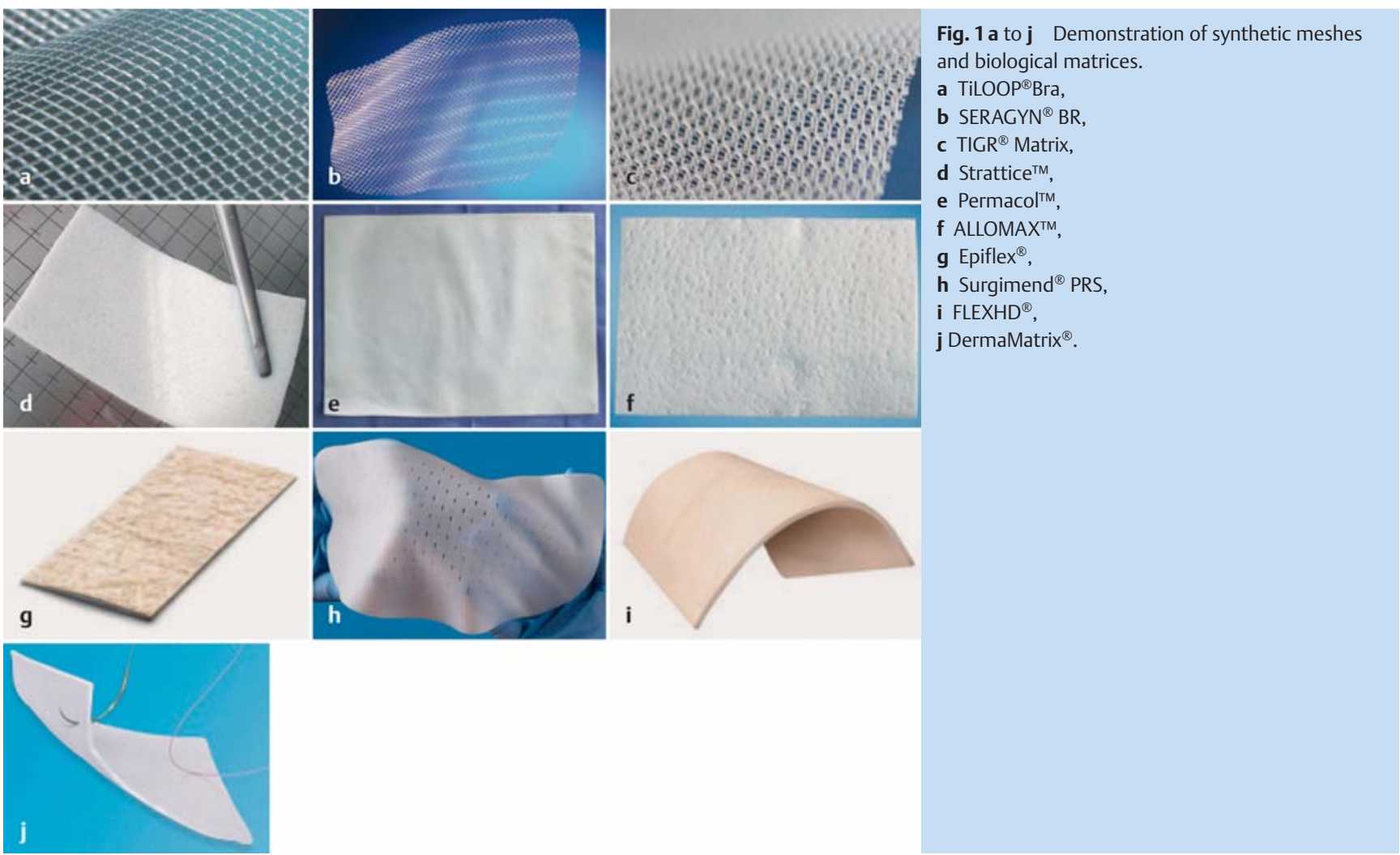

Table 2 Overview of biological meshes approved for breast reconstruction in Germany.

\begin{tabular}{|c|c|c|c|c|c|c|c|}
\hline & Strattice ${ }^{T M}$ & epiflex ${ }^{\circledR}$ & Permacol $^{\mathrm{TM}}$ & $\begin{array}{l}\text { SurgiMend }{ }^{\circledR} \\
\text { PRS }\end{array}$ & ALLOMAX'M & Flex HD ${ }^{\circledR}$ & DermaMatrix $^{\circledR}$ \\
\hline Source & $\begin{array}{l}\text { porcine- } \\
\text { derived matrix } \\
\text { (non-cross- } \\
\text { linked) }\end{array}$ & $\begin{array}{l}\text { human skin } \\
\text { (non-cross- } \\
\text { linked) }\end{array}$ & $\begin{array}{l}\text { porcine } \\
\text { dermal matrix } \\
\text { (cross-linked) }\end{array}$ & $\begin{array}{l}\text { fetal bovine } \\
\text { dermal collagen } \\
\text { (non-cross- } \\
\text { linked) }\end{array}$ & $\begin{array}{l}\text { human- } \\
\text { derived matrix } \\
\text { (non-cross- } \\
\text { linked) }\end{array}$ & $\begin{array}{l}\text { human allograft } \\
\text { skin (non-cross- } \\
\text { linked) }\end{array}$ & $\begin{array}{l}\text { human skin } \\
\text { (non-cross-linked) }\end{array}$ \\
\hline $\begin{array}{l}\text { Decellularization/ } \\
\text { processing }\end{array}$ & n.a. & n. a. & n. a. & n.a. & $\begin{array}{l}\text { acetone, } \\
\text { hyper/hypo- } \\
\text { tonic baths, } \\
\mathrm{H}_{2} \mathrm{O}_{2}, \mathrm{NaOH}\end{array}$ & hypertonic bath & $\begin{array}{l}\text { sodium chloride } \\
\text { and detergent, } \\
\text { disinfected with } \\
\text { acidic and anti- } \\
\text { septic reagents }\end{array}$ \\
\hline Sterilization & $\begin{array}{l}\text { electron beam } \\
\text { radiation }\end{array}$ & $\begin{array}{l}\text { peracetic } \\
\text { acid-based } \\
\text { sterilization }\end{array}$ & $\begin{array}{l}\text { gamma } \\
\text { radiation }\end{array}$ & ethylene oxide & $\begin{array}{l}\text { gamma } \\
\text { radiation }\end{array}$ & $\begin{array}{l}\text { decontamination } \\
\text { with ethanol and } \\
\text { peracetic acid } \\
\text { (not terminally } \\
\text { sterilized) }\end{array}$ & $\begin{array}{l}\text { disinfection } \\
\text { solution }\end{array}$ \\
\hline Thickness & $1-2 \mathrm{~mm}$ & $\begin{array}{l}>0.3 \text { and } \\
>0.8 \mathrm{~mm}\end{array}$ & $0.5-1.5 \mathrm{~cm}$ & $\begin{array}{l}0.4-0.75 \text { and } \\
0.75-1.54 \mathrm{~mm}\end{array}$ & $0.8-1.8 \mathrm{~mm}$ & $\begin{array}{l}0.4-0.8 \mathrm{~mm} \text { and } \\
0.8-1.7 \mathrm{~mm} \text { and } \\
1.8 \mathrm{~mm}\end{array}$ & $\begin{array}{l}0.2-04 \mathrm{~mm} \text { and } \\
0.4-0.8 \mathrm{~mm} \text { and } \\
0.8-1.7 \mathrm{~mm} \text { and } \\
1.7+\mathrm{mm}\end{array}$ \\
\hline $\begin{array}{l}\text { Tensile strength } \\
\text { (grab test) }\end{array}$ & $270 \mathrm{~N} / \mathrm{cm}$ & $70 \mathrm{~N} / \mathrm{cm}$ & $66 \mathrm{~N} / \mathrm{cm}$ & $432 \mathrm{~N} / \mathrm{cm}$ & $290 \mathrm{~N} / \mathrm{cm}$ & $929 \mathrm{~N} / \mathrm{cm}$ & $146 \mathrm{~N} / \mathrm{cm}$ \\
\hline $\begin{array}{l}\text { Physiological elas- } \\
\text { ticity at } 16 \mathrm{~N} / \mathrm{cm}\end{array}$ & $9.6 \%$ & n. a. & $13.1 \%$ & $6.4 \%$ & $26.2 \%$ & $21.2 \%$ & n. a. \\
\hline
\end{tabular}

n. a.: not available, $\mathrm{cm}$ : centimeter, mm: millimeter, N: Newton

\section{TIGR $^{\circledR}$ Matrix}

TIGR $^{\circledR}$ Matrix (Novus Scientific AB, Uppsala, Sweden) is a longterm resorbable synthetic mesh. The product description "matrix" is misleading, as the term is generally used to refer to biological products. Although, TIGR ${ }^{\circledR}$ Matrix is completely resorbable, it was classified as a synthetic mesh in our review because it is manufactured synthetically. After implantation, the synthetic fibers degrade at different rates by bulk hydrolysis ( Fig. 2). It provides additional support in the first six months, and complete resorption is achieved after three years. In vivo investigations in a three-year preclinical implantation study revealed good biocompatibility with the formation of blood vessels 


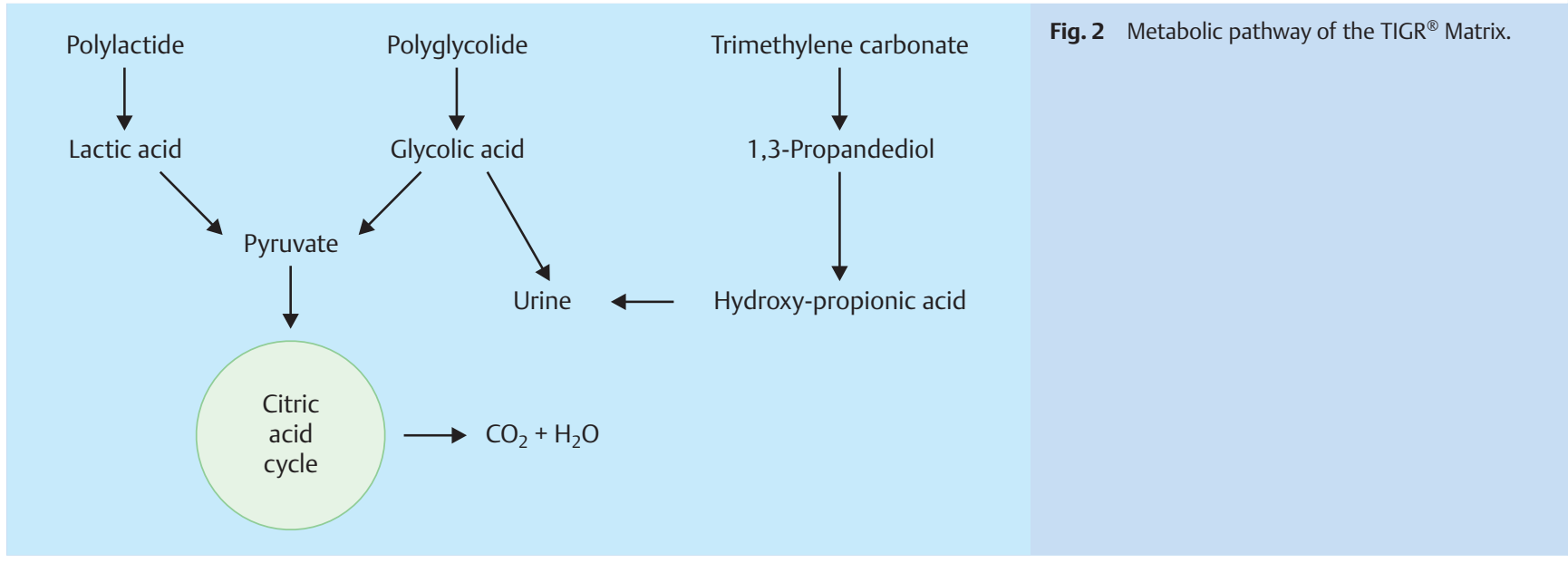

and well structured collagen fibers [13]. Data on TIGR ${ }^{\circledR}$ Matrix are predominantly available for hernia surgery. No clinical data are available with the exception of a retrospective study (LoE4) of 62 patients (112 breasts), which reported a complication rate of $19 \%$ (10.7\% in regards to operated breasts) [14]. A clinical evaluation of this mesh is being performed at Akademikliniken in Stockholm, Sweden. Final results are not yet available.

\section{Biological matrices}

Strattice ${ }^{\mathrm{TM}}$

Strattice $^{\mathrm{TM}}$ (LifeCell Corp., Branchburg, NJ, USA) is a terminally sterilized porcine-derived ADM denuded of antigenic cells ( Fig. 1) [15]. A complex proprietary process is performed to remove cells and key components believed to play an important role in the xenogenic rejection process without destroying the biochemical components needed for reinforcement. The Strattice ${ }^{\mathrm{TM}}$ encourages tissue regeneration, acting like a scaffold to be repopulated and revascularized by the host [16]. There are $17 \mathrm{ci}-$ tations in PubMed on the use of the Strattice ${ }^{\mathrm{TM}}$ in BR. A publication by Spears et al. (LoE 4) investigating mainly revisionary breast surgeries (92\%) reported an overall complication rate of 5.3\% [17]. Long-term studies over 3.5 years (LoE 4) in 105 BR reported a total complication rate of $8.6 \%$ [18].

\section{Permacol ${ }^{\mathrm{TM}}$}

Like Strattice $^{\mathrm{TM}}$, Permacol ${ }^{\mathrm{TM}}$ is a porcine-derived collagen tissue matrix from which cell debris, DNA and RNA are removed, leaving behind an acellular dermal scaffold. During processing, Permacol $^{\mathrm{TM}}$ is cross-linked, presumably to increase tensile strength compared to non-cross-linked ADMs. However, the cross-linking process changes the individual collagen strands, resulting in a less flexible matrix. Permacol ${ }^{\mathrm{TM}}$ has been primarily used in abdominal hernia repair, and clinical reports on its use in BR are not available.

\section{ALLOMAXTM}

ALLOMAX $^{\text {TM }}$ (BARD, Davol Inc., Warwick, RI, USA) is a non-crosslinked, regenerative collagen matrix derived from human dermis. During processing, all non-collagenous cell components are removed, leaving behind a sterile matrix of elastin fibers. The trademarked Tutoplast ${ }^{\mathrm{TM}}$ process first removes lipids, red and white blood cells and disrupts cell membranes, using an osmotic treatment to remove cellular components. Immunogenic formations are removed by an oxidative treatment. In vitro, high concentra- tions of vascular endothelial growth factor were found and blood vessel formation was observed [19]. In vitro investigations comparing Alloderm ${ }^{\mathrm{TM}}$ and ALLOMAX ${ }^{\mathrm{TM}}$ showed greater neovascularization, tissue infiltration, fibroblast proliferation and inflammatory reaction for Alloderm ${ }^{\mathrm{TM}}$. Clinical results for ALLOMAX ${ }^{\mathrm{TM}}$ are not available. ALLOMAX ${ }^{\mathrm{TM}}$ was formerly marketed as NeoForm $^{\circledR}$ (Mentor ${ }^{\circledR}$, Santa Barbara, CA, USA). A publication by Losken on the use of NeoForm ${ }^{\circledR}$ in 31 breasts reported no postoperative complications and vascular integration after three months [20].

\section{Epiflex $^{\circledR}$}

Epiflex $^{\circledR}$ (Deutsches Institut für Zell- und Gewebeersatz [DIZG] gGmbH, Berlin, Germany) is the only ADM approved as a drug in Europe. It is derived from human skin and undergoes a complex decellularization process, leaving behind a collagen matrix with low residual levels of genomic material insufficient to provoke an immune reaction. Histological analysis showed good cell infiltration with neoangiogenesis and tissue regeneration [21]. Clinical data on the use of Epiflex ${ }^{\circledR}$ in BR are not available in PubMed. Epiflex ${ }^{\circledR}$ is identical to DermaMatrix ${ }^{\circledR}$ and FlexHD ${ }^{\circledR}$, and the clinical results for these products are transferable.

\section{SurgiMend ${ }^{\circledR}$ PRS}

SurgiMend ${ }^{\circledR}$ PRS (TEI, Biosciences, Inc., Boston, MA, USA) is derived from fetal bovine dermal collagen and is rich in type III collagen. Collagen III is prominent in embryologic development and wound healing. It is the only biological mesh with fenestration, theoretically allowing fluid accumulations around the implant to drain into the surrounding tissue. Histological examination showed a decreased inflammatory response compared to other bovine-derived matrices [22]. Four months after SurgiMend ${ }^{\circledR}$ PRS implantation, adequate vascularization with CD31 positive cells was observed [23]. There are four publications available in PubMed on SurgiMend ${ }^{\circledR}$. The largest cohort reported on in a study by Butterfield consisted of 222 patients who had immediate IBBR with SurgiMend ${ }^{\circledR}$ [24]. Complication rates did not differ from those reported for Alloderm ${ }^{\mathrm{TM}}$ reconstructions. Seromas were the most commonly observed complications, with an incidence of $8.3 \%$. A recent publication on 95 procedures using SurgiMend ${ }^{\circledR}$ described 3.2\% hematomas, 7.5\% seromas and a re-operation rate of $2.1 \%$ [25]. 


\section{FlexHD ${ }^{\circledR}$}

FlexHD ${ }^{\circledR}$ (MTF/Ethicon, Inc., Somerville, NJ, USA) is an acellular hydrated dermis derived from cadaveric human allograft skin. During sterile processing, this matrix undergoes an aseptic process, removing the epidermis and dermis but maintaining the extracellular matrix responsible for tissue strength. In contrast to Epiflex $^{\circledR}$, which is deep-frozen, FlexHD ${ }^{\circledR}$ is conserved in alcohol. The study by Orenstein et al. found an increased inflammatory response for FlexHD ${ }^{\circledR}$ compared to Alloderm ${ }^{\mathrm{TM}}$ [26]. However, no difference in inflammation, neovascularization, adhesion or fibrous tissue was observed compared to Strattice ${ }^{\mathrm{TM}}$ [27]. Clinical experiences are mentioned in only 2 publications. In one large study of 547 BR procedures in 382 consecutive women, the majority $(81 \%)$ of whom had immediate reconstruction, no difference in complications was observed between Alloderm ${ }^{\mathrm{TM}}$ and FlexHD ${ }^{\circledR}[28]$. The overall rate of return to the operating room was $8.6 \%$. Surgical site infections occurred in $9.7 \%$, seromas in $6.0 \%$ and implant loss in $6.9 \%$. Although complication rates were comparable, an increased risk for implant loss was seen for the FlexHD ${ }^{\circledR}$ group in multivariate analysis $(p=0.042)$. In 284 BR procedures using AlloDerm ${ }^{\mathrm{TM}}$, DermaMatrix ${ }^{\mathrm{TM}}$ or FlexHD ${ }^{\mathrm{TM}}$, no significant differences in complication rates were observed [29]. In patients without ADM reconstruction, complications rates were much lower compared to the three ADM groups (2 vs. 10\%).

\section{DermaMatrix ${ }^{\circledR}$}

DermaMatrix $^{\circledR}$ (MTF/Synthes CMF, West Chester, PA, USA) is derived from human skin and undergoes an equivalent manufacturing process to that of FlexHD ${ }^{\circledR}$ during which the epidermis and dermis are removed. After implantation, cells promoting neovascularization and fibroblast deposits infiltrate the matrix. A retrospective study of 50 patients who had immediate expander BR using Alloderm ${ }^{\mathrm{TM}}$ or DermaMatrix ${ }^{\circledR}$ showed a comparable overall complication rate of $4 \%$ [30]. Neovascularization was similar for Alloderm ${ }^{\mathrm{TM}}$ and DermaMatrix ${ }^{\circledR}$.

\section{Discussion}

$\nabla$

Biological matrices and synthetic meshes are increasingly being incorporated into breast surgery. Many different materials are available, but it is still unclear which material is best. The most data is available for Alloderm ${ }^{\mathrm{TM}}$, a human-derived dermis used in the USA but not approved in Europe. Prospective randomized trials are not available for any matrix or mesh. Use of particular matrices or meshes depends predominately on single surgeon experiences or retrospective studies. No data is available which would indicate that any matrix is superior to others, and the potential increase in the number of seromas and the subsequent infections, inflammatory reactions and cases with capsular contraction are unknown. So far, the available publications show similar complication rates compared to IBBR without ADM or meshes [31]. Complication rates range between $17.7-29.0 \%$ for the titanium-coated mesh and $0-32 \%$ for biological matrices, whereas complications after IBBR without additional use of a matrix/mesh are reported to be about $15 \%[16,31-36]$.

Comparing individual studies results in a methodological bias which is partially responsible for the conflicting outcomes and the large range of reported complications. Defining complications using retrospective analysis is tricky, and direct comparisons are difficult. A meta-analysis by Sbitany and Serletti found no differences in infection rates of patients undergoing BR using
ADM compared to those with no ADM [37]. In contrast, Kim et al. found significant differences in seroma rates and overall complications in patients with IBBR using ADM [38]. The products used differ with regard to their manufacturing processes, and clinically significant differences in seroma formation rates were found for different matrices [39]. For synthetic meshes, only two strong publications reporting seroma rates of $1.8-4.8 \%$ are available [ 10 , 11]. Due to the limited number of publications, these numbers need to be interpreted carefully, and differences between synthetic meshes and biological matrices are speculative. One reason for the different seroma formation rates could be attributable to the surface properties of the respective materials. Biological matrices have smooth surfaces, permitting increased fluctuation between the matrix and subcutaneous tissue and resulting in the development of seromas. Synthetic meshes have rougher surfaces compared to ADMs, allowing for a potentially faster interaction between the mesh and the subcutaneous tissue, with less fluctuation and a consequent decrease in seroma formation. However, the rough surface can also serve as an additional stimulus for seromas. To what extent the different coatings of the synthetic meshes influence seroma formation rates remains unclear. From a clinical perspective and based on our own experiences, synthetic meshes should be used preferentially in primary cases with "sufficient" soft tissue. Defining "sufficient" soft tissue is difficult; there are no clinical guidelines. Evaluating the soft tissue left in situ after SSM/NSM depends on the personal assessment of each surgeon. No metric data have been evaluated in any scientific publication on biological matrices or synthetic meshes. Therefore, it is not possible to provide metric recommendations on the use of specific materials for certain soft tissue thicknesses. A retrospective study examining the postoperative results of IBBR using TiLOOP ${ }^{\circledR}$ Bra indicated an increased risk of complications for secondary BR [11]. Synthetic meshes are much thinner than biological matrices and not suitable for soft tissue replacement. They are useful in primary cases to define the inframammary fold, stabilize the implant laterally and prevent the implant from bottoming out [40]. Especially in secondary cases or revisionary breast surgery (aesthetic or reconstructive), the skin-soft tissue conditions are poor, compared to primary cases. Here, biological matrices could serve as a better alternative (OTable $\mathbf{3}$ ). The downside of biological matrices is that they are far more expensive than synthetic meshes. Both materials are valuable for BR but are not covered by the German Diagnosis Related Group (DRG) system and involve additional costs. With evolving surgical procedures, it is essential that costs and postoperative outcomes are taken into account. Single-stage implant reconstruction with ADM is associated with lower costs compared to twostage expander/implant reconstruction, even when the probability of complications is factored into the analysis [41]. A study by Krishnan et al. compared patients undergoing immediate autologous BR to patients undergoing IBBR using ADM. A cost-effectiveness analysis showed that ADM was not cost-effective compared to autologous $B R$ when the complication rate for autologous dermal flaps was below 20 percent [42]. A systemic review of infections after BR comparing autologous flaps to implant-based BR analyzed 39406 BR and found comparable infection rates of $5.28 \%$ for implant-based and $4.70 \%$ for autologous BR procedures [43]. Biological matrices should preferably be used in single-stage IBBR, as increased complications were observed for two-stage implant reconstructions [34].

In irradiated breasts, biological matrices and IBBR seem to give acceptable results [44]. If radiation therapy is indicated after 
Table 3 Recommendations for the application of synthetic meshes or biological matrices in implant-based breast reconstruction.

\begin{tabular}{|lll|}
\hline Indication and benefits & $\begin{array}{l}\text { Synthetic } \\
\text { meshes }\end{array}$ & $\begin{array}{l}\text { Biological } \\
\text { matrix }\end{array}$ \\
\hline Skin- and nipple-sparing mastectomy & $\mathrm{XX}$ & $\mathrm{XX}$ \\
\hline Inherent breast deformities & $\mathrm{X}$ & $\mathrm{X}$ \\
\hline Implant-associated breast deformities & $\mathrm{X}$ & $\mathrm{XX}$ \\
\hline Implant exchange & $\mathrm{XX}$ & $\mathrm{XX}$ \\
\hline Fixation of the pectoralis major muscle & $\mathrm{XX}$ & $\mathrm{XX}$ \\
\hline Control of implant position & $\mathrm{XX}$ & $\mathrm{XX}$ \\
\hline Implant support & $\mathrm{X}$ & $\mathrm{XX}$ \\
\hline Implant coverage & - & $\mathrm{XX}$ \\
\hline Additional soft tissue replacement & - & $\mathrm{XX}$ \\
\hline $\begin{array}{l}\text { Implant-based breast reconstruction } \\
\text { after MRM }\end{array}$ & - & $\mathrm{XX}$ \\
\hline Breast reconstruction after radiotherapy & - & $\mathrm{X}$ \\
\hline $\begin{array}{l}\text { Delayed immediate breast reconstruction } \\
\text { (mastectomy with expander } \rightarrow \text { radiation } \rightarrow\end{array}$ & - & $\mathrm{XX}$ \\
\hline final implant exchange) & & \\
\hline Decreased frequency of capsular contraction & unknown & unknown \\
\hline
\end{tabular}

X: recommended; XX: preferably recommended; -: not recommended, MRM: modified radical mastectomy

mastectomy, immediate delayed reconstruction (SSM/NSM with expander reconstruction followed by radiation therapy and subsequent expander to implant exchange) with ADM can be an alternative for patients desiring immediate BR instead of secondary BR. In an experimental study of rats, radiated implants covered with ADM had less capsular tensile strength, less inflammatory cell invasion, less thinning of the ADM and less pseudoepithelium formation [45]. These results suggest that the use of ADM in immediate delayed BR could reduce radiation-associated inflammation and decrease the incidence of capsular formations. These data need careful interpretation and BR should be delayed when radiation therapy is indicated after mastectomy [46]. In irradiated patients, secondary BR with autologous tissue remains the procedure of choice.

A surgical alternative to the described matrices and meshes is available for patients with large, ptotic breasts where the patient's own autologous dermal tissue can be used by de-epithelizing the inferior mastectomy flap. This flap can then be used in the same way as a matrix/meshes to stabilize the implant pocket and protect the implant [47].

When deciding on the choice of material to be used during surgery, proper preoperative assessment is essential. Both product groups should be available during surgery to allow the surgeon to make the "right" decision.

If it is doubtful whether an attractive postoperative result can be created using implants, an experienced breast surgeon needs to discuss autologous reconstruction in advance with the patient [48]. Although biological matrices and synthetic meshes can facilitate BR, they are not "miracle products" capable of solving every problem associated with IBBR. Some manufacturers may argue that their product is superior to others, but long-term results, for example the incidence of lasting complications such as capsule contraction, are still pending for all materials presented here. Especially in complicated reconstructive situations with poor soft tissue conditions, autologous procedures are preferable as they usually have lower complication rates when performed by experienced surgeons in high-volume hospitals $[49,50]$.
It is essential to evaluate the need for a supplementary product preoperatively. It is also important to keep in mind that only biological matrices should be used for soft tissue replacement. Synthetic meshes can serve as auxiliary supports to define the inframammary fold and stabilize the implant pocket but are not meant to be used as tissue replacement. If possible, the surgeon should abstain from using a second product, as the use of two foreign bodies (implant and matrix/mesh) will increase graft reaction and possible complications. Biological matrices and synthetic meshes have an important part to play in breast reconstruction in selected patients.

\section{Funding}

All costs were covered by the hospital and the authors themselves. No funding from third parties was received.

\section{Conflict of Interest \\ $\nabla$}

Prof. Faridi is a consultant for pfm medical and DIGZ. Dr. Dieterich received research funds from $\mathrm{KCI} /$ Lifecell, pfm medical and Serag Wiessner.

\section{References}

1 Gerber B, Krause A, Dieterich M et al. The oncological safety of skin sparing mastectomy with conservation of the nipple-areola complex and autologous reconstruction: an extended follow-up study. Ann Surg 2009; 249: 461-468

2 Albornoz CR, Bach PB, Mehrara BJ et al. A paradigm shift in U.S. Breast reconstruction: increasing implant rates. Plast Reconstr Surg 2013; 131: 15-23

3 Beier J, Arkudas A, Horch R. [Is there a paradigm shift in reconstructive breast surgery?]. Gibt es einen Paradigmenwechsel in der rekonstruktiven Brustchirurgie? GMS Ger Plast Reconstr Aesthet Surg 2013; 3: Doc01

4 Spear SL, Pelletiere CV. Immediate breast reconstruction in two stages using textured, integrated-valve tissue expanders and breast implants. Plast Reconstr Surg 2004; 113: 2098-2103

5 Spear SL, Parikh PM, Reisin E et al. Acellular dermis-assisted breast reconstruction. Aesthetic Plast Surg 2008; 32: 418-425

6 Breuing $K H$, Warren SM. Immediate bilateral breast reconstruction with implants and inferolateral AlloDerm slings. Ann Plast Surg 2005; 55: 232-239

7 Scheidbach H, Tannapfel A, Schmidt $U$ et al. Influence of titanium coating on the biocompatibility of a heavyweight polypropylene mesh. An animal experimental model. Eur Surg Res 2004; 36: 313-317

8 Dieterich $M$, Dieterich $H$, Timme $S$ et al. Using a titanium-coated polypropylene mesh (TiLOOP ${ }^{\circledR}$ Bra) for implant-based breast reconstruction: case report and histological analysis. Arch Gynecol Obstet 2012; 286: 273-276

9 Dieterich M, Gerber B, Reimer T et al. Biokompatibilität synthetischer und biologischer Netze im Rahmen der implantatgestützen Brustrekonstruktion. Posterbeitrag, Senologiekongress München 2013

10 Dieterich $M$, Reimer $T$, Dieterich $H$ et al. A short-term follow-up of implant based breast reconstruction using a titanium-coated polypropylene mesh (TiLoop((R)) Bra). Eur J Surg Oncol 2012; 38: 1225-1230

11 Dieterich M, Paepke S, Zwiefel K et al. Implant-based breast reconstruction using a titanium-coated polypropylene mesh (TiLOOP Bra): a multicenter study of 231 cases. Plast Reconstr Surg 2013; 132: 8e-19e

12 Paepke SKE, Dittmer S, Ohlinger $R$ et al. Einsatz des teilresorbierbaren Zweikomponenten-Polypropylen-Vicryl-Meshs (SERAGYN ${ }^{\circledR}$ BR) als Gewebeinterponat in der plastisch-rekonstruktiven Mammachirurgie - Erste Erfahrungen. Abstract, Kongressbeitrag Senologiekongress 2012 
13 Hjort H, Mathisen T, Alves A et al. Three-year results from a preclinical implantation study of a long-term resorbable surgical mesh with timedependent mechanical characteristics. Hernia 2012; 16: 191-197

14 Becker H, Lind JG 2nd. The use of synthetic mesh in reconstructive, revision, and cosmetic breast surgery. Aesthetic Plast Surg 2013; 37: 914-921

15 KCIs LifeCell Granted CE Mark for its Strattice ${ }^{\circledR}$ Reconstructive Tissue Matrix. Online: www.kci-medical.de/DE-GER/strattice; last access: 12.07.2013

16 Ibrahim AM, Ayeni OA, Hughes KB et al. Acellular dermal matrices in breast surgery: a comprehensive review. Ann Plast Surg 2013; 70: 732-738

17 Spear SL, Sinkin JC, Al-Attar A. Porcine acellular dermal matrix (strattice) in primary and revision cosmetic breast surgery. Plast Reconstr Surg 2013; 131: 1140-1148

18 Salzberg CA, Dunavant C, Nocera N. Immediate breast reconstruction using porcine acellular dermal matrix (Strattice): long-term outcomes and complications. J Plast Reconstr Aesthet Surg 2013; 66: 323-328

19 Orenstein SB, Qiao Y, Kaur M et al. Human monocyte activation by biologic and biodegradable meshes in vitro. Surg Endosc 2009; 24: 805811

20 Losken A. Early results using sterilized acellular human dermis (Neoform) in post-mastectomy tissue expander breast reconstruction. Plast Reconstr Surg 2009; 123: 1654-1658

21 DIZG Deutsches Institut für Zell- und Gewebeersatz Gemeinnützige Gesellschaft $\mathrm{mbH}$. Online: http://epiflex.de/files/epiflex-brustchirurgie. pdf; last access: 21.03.2013

22 Hwang K, Hwang JH, Park JH et al. Experimental study of autologous cartilage, acellular cadaveric dermis, lyophilized bovine pericardium, and irradiated bovine tendon: applicability to nasal tip plasty. J Craniofac Surg 2007; 18: 551-558

23 Craft RO, May jr. JW. Staged nipple reconstruction with vascularized SurgiMend acellular dermal matrix. Plast Reconstr Surg 2011; 127: $148 \mathrm{e}-149 \mathrm{e}$

24 Butterfield JL. 440 Consecutive immediate, implant-based, single-surgeon breast reconstructions in 281 patients: a comparison of early outcomes and costs between SurgiMend fetal bovine and AlloDerm human cadaveric acellular dermal matrices. Plast Reconstr Surg 2013; 131: 940-951

25 Ohkuma R, Buretta KJ, Mohan R et al. Initial experience with the use of foetal/neonatal bovine acellular dermal collagen matrix (SurgiMend) for tissue-expander breast reconstruction. J Plast Reconstr Aesthet Surg 2013; 66: 1195-1201

26 Orenstein S, Qiao Y, Kaur M et al. In vitro activation of human peripheral blood mononuclear cells induced by human biologic meshes. J Surg Res 2010; 158: 10-14

27 Ngo MD, Aberman HM, Hawes ML et al. Evaluation of human acellular dermis versus porcine acellular dermis in an in vivo model for incisional hernia repair. Cell Tissue Bank 2011; 12: 135-145

28 Liu DZ, Mathes DW, Neligan PC et al. Comparison of outcomes using AlloDerm versus FlexHD for implant-based breast reconstruction. Ann Plast Surg 2013; DOI: 10.1097/SAP.0b013e318268a87c

29 Brooke S, Mesa J, Uluer M et al. Complications in tissue expander breast reconstruction: a comparison of AlloDerm, DermaMatrix, and FlexHD acellular inferior pole dermal slings. Ann Plast Surg 2012; 69: 347-349

30 Becker S, Saint-Cyr M, Wong C et al. AlloDerm versus DermaMatrix in immediate expander-based breast reconstruction: a preliminary comparison of complication profiles and material compliance. Plast Reconstr Surg 2009; 123: 1-6; discussion 107-108

31 Petersen A, Eftekhari AL, Damsgaard TE. Immediate breast reconstruction: a retrospective study with emphasis on complications and risk factors. J Plast Surg Hand Surg 2012; 46: 344-348
32 Cordeiro PG, Snell L, Heerdt A et al. Immediate tissue expander/implant breast reconstruction after salvage mastectomy for cancer recurrence following lumpectomy/irradiation. Plast Reconstr Surg 2012; 129: 341-350

33 Chun YS, Verma K, Rosen $\mathrm{H}$ et al. Implant-based breast reconstruction using acellular dermal matrix and the risk of postoperative complications. Plast Reconstr Surg 2010; 125: 429-436

34 Weichman KE, Wilson SC, Weinstein AL et al. The use of acellular dermal matrix in immediate two-stage tissue expander breast reconstruction. Plast Reconstr Surg 2012; 129: 1049-1058

35 Peled AW, Foster RD, Garwood ER et al. The effects of acellular dermal matrix in expander-implant breast reconstruction after total skinsparing mastectomy: results of a prospective practice improvement study. Plast Reconstr Surg 2012; 129: 901e-908e

36 Salzberg CA, Dunavant C, Nocera N. Immediate breast reconstruction using porcine acellular dermal matrix (Strattice): Long-term outcomes and complications. J Plast Reconstr Aesthet Surg 2012; 66: 323-328

37 Sbitany H, Serletti JM. Acellular dermis-assisted prosthetic breast reconstruction: a systematic and critical review of efficacy and associated morbidity. Plast Reconstr Surg 2011; 128: 1162-1169

$38 \mathrm{Kim}$ JY, Davila AA, Persing S et al. A meta-analysis of human acellular dermis and submuscular tissue expander breast reconstruction. Plast Reconstr Surg 2012; 129: 28-41

39 Michelotti BF, Brooke S, Mesa J et al. Analysis of clinically significant seroma formation in breast reconstruction using acellular dermal grafts. Ann Plast Surg 2013; 71: 274-277

40 Dieterich M, Gerber B. Patient selection and technical considerations in nipple-sparing and areola-sparing mastectomy. Curr Breast Cancer Rep 2011; 3: 79-87

41 de Blacam C, Momoh AO, Colakoglu S et al. Cost analysis of implantbased breast reconstruction with acellular dermal matrix. Ann Plast Surg 2012; 69: 516-520

42 Krishnan NM, Chatterjee A, Van Vliet MM et al. A comparison of acellular dermal matrix to autologous dermal flaps in single-stage, implantbased immediate breast reconstruction: a cost-effectiveness analysis. Plast Reconstr Surg 2013; 131: 953-961

43 Danovic $S$, Phillips B, Verma $R$ et al. A systemic review of infections in breast reconstruction: autologous flap versus implant reconstruction. Plast Reconstr Surg 2013; 131 (PS RC 2013 Abstract Supplement 5s): 3-192

44 Nahabedian MY. AlloDerm performance in the setting of prosthetic breast surgery, infection, and irradiation. Plast Reconstr Surg 2009; 124: $1743-1753$

45 Komorowska-Timek E, Oberg KC, Timek TA et al. The effect of AlloDerm envelopes on periprosthetic capsule formation with and without radiation. Plast Reconstr Surg 2009; 123: 807-816

46 Kronowitz SJ. Current status of implant-based breast reconstruction in patients receiving postmastectomy radiation therapy. Plast Reconstr Surg 2012; 130: 513e-523e

47 Nava MB, Cortinovis U, Ottolenghi J et al. Skin-reducing mastectomy. Plast Reconstr Surg 2006; 118: 603-610; discussion 611-603

48 Dieterich $M$, Dieterich $H$, Nestle-Krämling $C$ et al. Certification of breast surgeons in Germany - AWO-gyn curriculum in an international comparison. Geburtsh Frauenheilk 2009; 69: 987-991

49 Albornoz CR, Cordeiro PG, Hishon L et al. A nationwide analysis of the relationship between hospital volume and outcome for autologous breast reconstruction. Plast Reconstr Surg 2013; 132: 192e-200e

50 Endara $M$, Chen D, Verma Ket al. Breast reconstruction following nipple sparing mastectomy; a systematic review of the literature with pooled analysis. Plast Reconstr Surg 2013; DOI: 10.1097/PRS.0b013e3182a48 b8a 